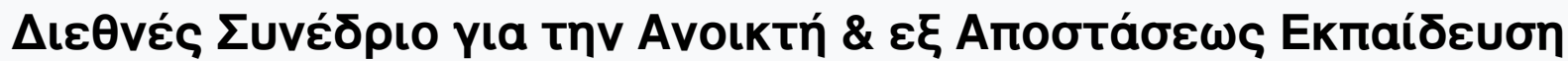

Tóp. 7, Ap. 6B (2013)

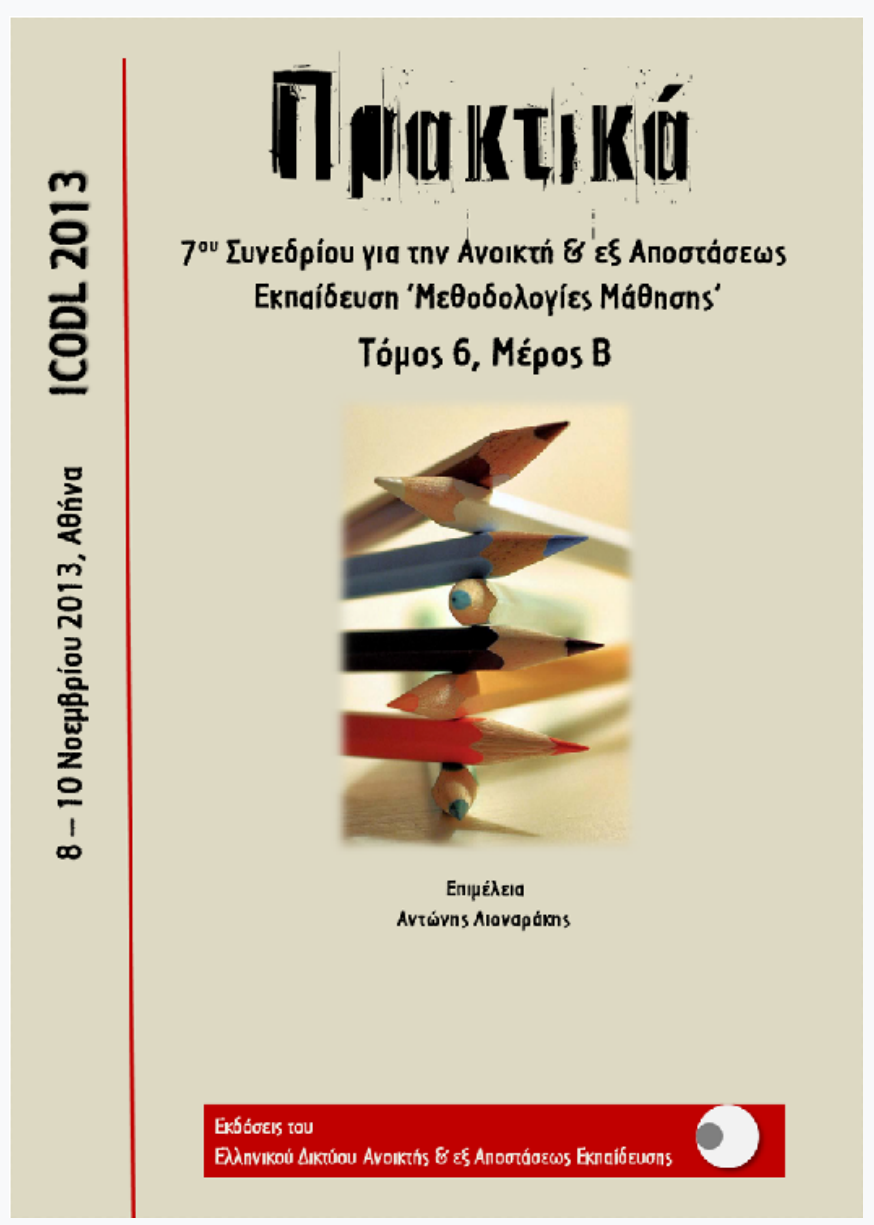

Connecting generations, connecting civil society in Europe. A Grundtvig learning partnership: The Greek experience

Suzanne Antonaros, Gilda Esposito, Evangelia Manousou, Susan Moutsouroufi, Eirini Moutzuris, Anastasia Papaionnou, Theresa Portell, Sofia Tanaini

doi: $\underline{10.12681 / \text { icodl. } 627}$ 


\title{
Connecting generations, connecting civil society in Europe. A Grundtvig learning partnership: The Greek experience
}

\author{
Suzanne Antonaros \\ Language Teacher Trainer \\ Living Values in Education \\ etc@ath.forthnet.gr
Susan Moutsouroufi English Teacher
Living Values in Education \\ susanmouts@yahoo.co.uk
}

\author{
Gilda Esposito \\ Project Coordinator \\ EDAFORUM Italy \\ gilda.esposito@unifi.it
}

\author{
Evangelia Manousou \\ Teacher, Tutor-Counselor \\ Living Values in Education \\ gellym@gmail.com
}

\author{
Theresa Portell \\ English Teacher \\ Living Values in Education \\ seasun1992@gmail.com
}

Eirini Moutzuris

IT Consultant, Trainer

Living Values in Education

emuath@gmail.com

\author{
Anastasia Papaionnou \\ Teacher \\ Living Values in Education \\ anastpapaioannou@gmail.com
}

\author{
Sofia Tanaini \\ Teacher \\ Living Values in Education \\ stanaini@gmail.com
}

\begin{abstract}
In 2012, the EU year of active ageing, the EU Lifelong Learning Programme invited civil society associations to take action on active ageing and intergenerational solidarity, from an educational standpoint. Nine associations from eight different countries decided to seize this opportunity and formulated "Connecting Generations", a two year Grundtvig learning partnership whose objective is to strengthen European learning networks and to contribute to the consolidation of Europe as a knowledge society and as a peaceful and socially cohesive region, while raising awareness and finding appropriate, concrete and measurable tools to meet the challenges of active ageing. In the first year and half of implementation, the partners have met in five countries, mobilizing more than fifty people. Connecting Generations has been locally realized using innovative practices that have enhanced dialogue between generations. Dialogues that have and are currently being interpreted into activities where the elderly actively interact with younger generations and the voices of all are heard through traditions, story telling, song, arts, crafts... Old and young, have enjoyed the pleasure of listening to each other without prejudices, as members of a common human community, a community that has a great responsibility toward future generations.The World Café joins Connecting Generations in connecting values.
\end{abstract}

Keywords: lifelong learning, connecting generations, world café, active listening, conversations, living values

\section{Instruction}

This learning partnership is the result of a collective collaborative project started in Villasimus, Italy, during a contact seminar organised by the Italian LLP Agency, and 
that continued at distance and was further developed, building on common interests and visions, and finally translated into practices in order to develop strategies for lifelong learning and mobility and co-construction of knowledge and lessons learnt consistent with the Grundtvig priority of intergenerational learning and learning for senior citizens.

We are concerned that, while demographic transformation in our society is already a fact, our adult education organisations still lag behind in offering innovative paths for learning that can contribute to create better understanding among generations and bring forward CONGENIAL ways of living together. We consider that ICTs are a main challenge to face: elder people can greatly benefit from becoming more familiar with social networks and technology, acquiring a codified language to interact with young people. On the other hand, young people, through interaction with elders based on respect and active listening, will open their view and minds to non-technological aspects of our life, like art crafts, reading and narrative circles under a living value perspective.

We share two objectives:

a) To strengthen European learning networks, that are contributing to the consolidation of Europe as a knowledge society and as a peaceful and socially cohesive region;

b) To raise awareness and find appropriate, concrete and measurable answers to the ongoing challenges of active ageing.

\section{Rationale}

Global changes and their local consequences, digitalisation of our daily life and demographic ageing are transforming the relationships among generations and the way Europe, as well as local communities in member states, function. Never before has humanity witnessed such rapid changes in less than a century: grandparents, parents and young people/children are at risk of speaking different languages, using distant symbolic codification and living different lives. The future is uncertain, it has always been, but today our present is becoming an inextricable puzzle of diversity and distances.

The treaty of Lisbon states that the Union shall combat social exclusion and discrimination, and shall promote social justice and protection, equality between women and men, solidarity between generations and protection of the rights of the child. Europe 2020's pillar includes inclusive growth. 2012 is also the European Year for Active Ageing and Intergenerational Solidarity and the Commission calls the Member States to support the creation of an EU age-friendly environment network that would provide support to local, regional and national actors seeking to foster active and healthy ageing.

Therefore, as EU citizens, and as human beings in a globalised world, we need to take immediate and informed action to avoid inequality of opportunities, and any kind of division, that hinder the right of each person to grasp the best, and not the worst, out of post-modernisation and globalisation.

Rather than focusing on the negative side of ongoing transformation, which brings with it new challenges and coincides with a deep economic, and values crisis, our changing reality should be looked at as an opportunity to invert the path and enhance human development for all. Human development, according to UNDP, is "about creating an environment in which people can develop their full potential and lead productive, creative lives in accordance with their needs and interests." In order to create such an environment we need to work to abate inequalities and consequent 
discrimination, be it because of cultural, national background, age, sex or any other human characteristic. Our society has to urgently bring about solutions to many current economic and social challenges that cannot be faced with traditional, out of date, methods. Civil society, can greatly contribute to identify and value ongoing experimentation of new ways of living together, as well as producing brand new ones.

Education and training for lifelong learning (LLL) seem to us to be among the most appropriate path toward building such a renovated society. Lifelong learning as the continuous building of skills and knowledge throughout the life of an individual is key to impacting not only on the individual as such, but especially the ways he/she lives with and interacts with others within a society built on solidarity and respect.

According to Merriam Webster Dictionary, the adjective "congenial" means a) having the same nature, disposition, or tastes, b) existing or associated together harmoniously and c) PLEASANT especially agreeably suited to one's nature or tastes. Our partnership, as a result of a contact meeting organised by the Italian National Agency last October 2011 in Villasimius, Italy, was congenial! We committed to cooperate inward as well, and especially outward, with organisations and authorities at the national level, to ensure a sound basis for identifying, valuing and modeling ideas and activities and opening up channels for dissemination for further projects, both with local and possibly international funding. We consider this learning partnership as a collective learning circle, based on reciprocity, horizontality and limitless creativity that at the end of the two years process will have produced knowledge, friendship, understanding and respect of the richness of diversity, and therefore a better Europe.

Finally we have decided to create a broad definition of active ageing and intergenerational solidarity and an ample space for experimentation, according to each country characteristics and partner's experience and aspirations. In fact, according to the European Commission, and the Euro barometer, solidarity and the creation of links between younger and older generations should not be seen in strict financial terms, with negative effects on pensions and social costs. The Commission recommends placing equal importance on the promotion of mutual cooperation and interaction between generations, as well as better understanding of new forms of coexistence. Co-existence, co-construction of knowledge, living and sharing experiences together are the priorities of our learning partnership.

\section{Project Objectives-Goal and Approach}

To create in our local communities an enhancing environment conducive to intergenerational communication and mutual understanding that will lead to a better quality of life for all, through non formal and informal adult education activities carried out by the partner organisations

To produce and transfer knowledge, methods and good practice for senior citizen education and intergenerational learning through mobilities and a shared on line platform at European level which also includes Turkey.

Specific objective: "To develop innovative methods to foster communication and create learning opportunities between older and younger generations based on exchanging good practices of the participating organisations"

Problem: Different generations: grandparents, parents and young people/children are at risk of speaking different languages, not understanding each other and living 
different lives. We are witnessing an inextricable puzzle of diversity and distances. As EU citizens we need to take immediate and informed action to avoid inequality of opportunities that hinder the right of each person to exert full citizenship. Our challenge is to co-construct a citizens' knowledge society, with no distinction whatsoever based on age or sex or cultural provenience. That will come from a genuine communication among generations based on mutual curiosity and respect, in a living values atmosphere. The overall, long term, result will be a better quality of life for all generations. The concrete tool available to us is a rich portfolio of adult education initiatives.

\section{Approach}

a) Experimenting with innovative, non conventional forms of communication and learning to enhance mutual understanding and recognition between generations (world cafes, learning circles, e-mentoring)

b) Offering learning opportunities, based on participation and creativity to be shared and utilised by the old and the young, preserving and sharing cultural memories (e.g. traditional games, folk art, art crafts, etc.) as well as opening to the digital era (social media, ICTs in general)

c) Exchange good practices, through mobilities, a web platform and international seminars

d) Systematise all the above in a user-friendly e-publication

Through an attentive distant coordination and mobilities, we will define user friendly curricula and facilitator's guidelines that will constitute our common endowment and will be exploited and disseminated through an enlarged network.

\section{Methodologies-Impact/Outcomes}

A large percentage of our learners are senior. We are aware of the problems of communication and mutual understanding they face and we would like to exploit this partnership to offer them, and ourselves, a diverse and transnational learning space to build solutions together.

Our strategy is problem and result oriented and will impact at two levels:

I) At the local level, in each member state, every member organisation will develop or strengthen an already ongoing micro-experimentation of intergenerational learning, putting young and senior people in the condition of developing and reflecting on common learning and acting, in the principle of intergenerational communication and solidarity.

II) At the transnational level, each partner will share experience: through bilateral mobilities, during 3 international seminars (kick off, mid-term and final) and via an ad hoc e-learning platform on the web, that will be maintained by the Coordinator Association (EDA FORUM) and constantly fed into by each partner. The web site/platform, as a repository of all local experiences, will be the main tool of a joint exploitation and dissemination strategy.

The impact of the project can also be seen at the target recipients/beneficiaries level: will also benefit two targets categories: senior and younger learners on one side and associations and their staff, especially educators on the other.

1) Learners will develop skills and key competences that are valuable to exert full citizenship in Europe today 
2) Adult education operators will have their professional skills improved and will be therefore able to offer better adult education well beyond the end of the project.

The latter is also consistent with Grundtvig priority of quality assurance of adult learning, including the professional development of staff.

\section{Results \& Outcomes}

All 24 months

Consolidated network of organisations in Europe and Turkey supporting

intergenerational learning and linked with other similar networks (i.e. Age Platform)

1.1 Network agreement on web site

1.2 Action manifesto for intergenerational learning

First Year

Locally piloted intergenerational learning micro-projects, to be shared and enriched within the network

2.1 PPT on each experience methodology and tools to be posted on the web site

2.1 Video clips (zero cost) and pictures on dedicated social media

From 6-24 months

Identified and exchanged innovative methodologies for adult educators, through mobilities and job shadowing. A solid feeling of belonging to a common European society will be created.

3.1 Mobility reports

3.2 Exchange of best practices

Second year

E-publications of shared experience, piloted projects and research results on the CONGENIAL website

\section{The Greek Experience. Living Values in Education and Connecting Generations Overview}

This partnership, Connecting Generations, has been embraced by young and old with love and enthusiasm and in so doing demonstrates the need that exists for generations to communicate, the need to understand one another, and to recognizes what each generation has to offer.

Regarding our activities in Greece, the partnership has allowed for the voice of the third generation to be heard, not only in Athens, but also in Chios, Patras,Kavalaand Ermioni and at the same time has given youths the opportunity to voice their needs and concerns.

The greek participation focus on the implementation of the methodology of World Café (Brown, Isaacs, World Café Community, 2005)

The World Café methodology has stimulated open communication and a dialogue of equals between generations. From which has emerged the need for actions that brings generations closer and reveals the timeless values of cooperation, responsibility, honesty, love, peace, tolerance etc.

Participation in mobilities has allowed us to gain experience and knowledge of different approaches and methodologies, enriched with ideas and different perspectives that each group of participants.

\section{Activities}

The World Cafe As A Methodology For Establishing And Enhancing Communication Between Generations 
Connecting Generations and Living Values in Education, Greece, was introduced to the public at our kick-off World Café event, entitled"The Importance of Creativity for Learners of Every Age", held at a Primary School in Agios Dimitrios. Participants included, senior citizens from Love and Protection Centers for the Elderly (KAPH) of Agios Dimitrios and Agios Ioannis, Rendi, educators of different levels, and children from both districts. The central theme was "The Importance of Creativity for Learners of Every Age" and the ideas that came forth from the World Café gave birth to "Living Together" the theme we would use to threadall of the projects together.

The World Café as a methodology has been embraced by participating groups and organisations and in some circumstances has been adapted to include small children, as was the case in Nea Philadelphia where, the World Cafe themed "The Significance of Connecting Generations" lay the foundation for Connecting Generation events and celebrations to be organised in the area. Participants-grandparents, parents, educators and pupils-- discussed what each generation must do to foster the intragenerational 'connection' and specified in which activities, based on love, cooperation, solidarity, etc. each could participate.

The methodology, in combination with bringing together, the youthful enthusiasm of children, the cautious, busy nature of a $2^{\text {nd }}$ generation trying to make ends meet and the wisened perceptions of senior citizens, has allowed us to open up conversations that have resulted in unique and special outcomes. Outcomes that have not only helpedto shape and give form to projects but have also broadened our understanding, communication, co-operation, tolerance and compassion towards one another. Taking the first steps to integrating society through open conversations.

\section{Connecting Generations - Living Together}

Living Values in Education, Greece, as an educational body reached out its arm to members and invited them to actively participate in the Connecting Generations project with special focus on connecting senior citizens with younger generations. Our educators have taken this on board, and as facilitators have effectively brought together generations on a variety of project and events within their communities. Described briefly below are some of these experiences.

In the Municipality of Agios Dimitrios, Gelly Manousou, member of the board of the association of living Values in Education, created a footprint for "Living Together" in modeling a wide range of projects and activities wheresenior citizens connected with young people to share stories and experiences, sing songs past and present, cook and celebrate festivals together. In 'Love Stories'grandparentsre told stories of how they met and married, these stories were compiled into digital books. Celebrating together the national holiday of October 28, an interview style question and answer session on life during the $2^{\text {nd }}$ World War resulted in a poster on the topic. Sharing songs from the past opened up discussions between generations on the socio-historical importance and understanding of songs in their own era and their relevance today.

Eleni Aggelopoulou, facilitator, member of the association o Living Values, connected teenagers and senior citizens from the Municipality of Agios Ioannis Rendis. Elders shared their knowledge and experience, and in turn were inspired by the optimism, the energy and the enthusiasm of the teenagers who were there.

The delightful project by Louiza Michalakopoulou, member of the association of Living Values, had senior citizens and children connecting through the joy of play. Using the World Café as a teaching practice, generations connect to talk about games from the past and the values to be learned in the playing of games.

The partnership ends July 2014 and our individual projects are still ongoing. 


\section{Mobilities}

Sharing experiences through mobilities has been a very enriching experience for all participants on multiple levels.

- meeting peers, exchanging ideas, sharing experiences and working together,

- $\quad$ creating incentives for shared working experiences beyond connecting generations

- $\quad$ experiencing different methodologies first hand

- $\quad$ creating a better understanding of the socio-economic difficulties of each partner country

- $\quad$ fostering respect for Europe's cultural heritage.

\begin{tabular}{|c|c|c|c|}
\hline \multicolumn{4}{|c|}{ Other organizations participating in the Partnership: } \\
\hline $\begin{array}{c}\text { Name of Particpating } \\
\text { Organisation }\end{array}$ & Country & Co-Ordinators & Methedology \\
\hline $\begin{array}{l}\text { Eda Forum-Forum } \\
\text { Permanente per } \\
\text { l'Educazione degli Adulti - } \\
\text { Bagno a Ripoli }\end{array}$ & Florence,Italy & Gilda Esposito & $\begin{array}{l}\text { Systemetising and website, } \\
\text { Participatory research } \\
\text { action. }\end{array}$ \\
\hline $\begin{array}{l}\text { Merseyside Expanding } \\
\text { Horizons Ltd }\end{array}$ & Liverpool, UK & Nicola Daley & Community Mapping \\
\hline $\begin{array}{l}\text { Telos Kulturális Szolgáltató } \\
\text { Bt. EN: Telos Cultural } \\
\text { Provider Partnership }\end{array}$ & $\begin{array}{l}\text { Budapest, } \\
\text { Hungary }\end{array}$ & $\begin{array}{l}\text { Annamária } \\
\text { Csornay }\end{array}$ & Trainig for e-mentoring \\
\hline $\begin{array}{l}\text { AIDEA Ass. di Educazione } \\
\text { degli Adulti La Spezia }\end{array}$ & La Spezia, Italy & $\begin{array}{l}\text { Maria Gabriella } \\
\text { Peroni }\end{array}$ & $\begin{array}{l}\text { Language Cafes, } \\
\text { Story Telling, Conversations }\end{array}$ \\
\hline $\begin{array}{l}\text { Uniwersytet Trzeciego } \\
\text { Wieku w Białymstoku }\end{array}$ & Białystok, Poland & Danuta Sajur & \\
\hline $\begin{array}{l}\text { Universitatea Crestina } \\
\text { Dimitrie Cantemir, } \\
\text { Facultatea de Stiinte ale } \\
\text { Educatiei, FORUM }\end{array}$ & $\begin{array}{l}\text { Bucharest, } \\
\text { Romania }\end{array}$ & Octavia Costea & $\begin{array}{l}\text { Drama, Theatre as a means } \\
\text { of integrational dialogues. } \\
\text { OST (open space } \\
\text { technology) }\end{array}$ \\
\hline Posoški razvojni center & $\begin{array}{l}\text { Kobarid, } \\
\text { Slovenia }\end{array}$ & Almira Pirih & $\begin{array}{l}\text { Learning Circles, Learn by } \\
\text { doing. }\end{array}$ \\
\hline $\begin{array}{l}\text { MERCAN } \\
\text { ULUSLARARASI } \\
\text { GÖNÜLLÜLER DERNEĞİ }\end{array}$ & $\begin{array}{l}\text { AFYONKARAH } \\
\text { İSAR - Turkey }\end{array}$ & $\begin{array}{l}\text { Ayşe } \\
\text { DEMİROK }\end{array}$ & $\begin{array}{l}\text { Learn by doing, Arts and } \\
\text { Crafts }\end{array}$ \\
\hline $\begin{array}{l}\text { Axeis Zois, Living Values } \\
\text { in Education }\end{array}$ & Athens, Greece & Sophia Tanaini & $\begin{array}{l}\text { World Café } \\
\text { Active Listening } \\
\text { Green Values }\end{array}$ \\
\hline
\end{tabular}

\section{Conclusion}

Connecting Generations, Living Values and World Café has been an innovative and winning combination. What better way to connect generations than to open up and have honest conversations on who we are, what we do, where we come from, how we live, think, love... what better way than through a methodology whose essence requires us to listen actively and respectfully, a methodology that teaches us to cooperate in groups, to tolerate opinions, to work responsibly towards outcomes. A combination that has allowed for activities that has brought joy to ageing elders, in 
sharing their experiences, a greater understanding to youngsters eager to learn and grow into the world that surrounds them, and insight and perspectives to educators and parents. The World Café joins Connecting Generations in connecting values.

\section{Bibliography}

Brown, J., Isaacs, D., \&World Café Community (2005). The World Café: Shaping our Futures Though Conversations, That Matter, Berrett Koheler Publisers, INC, San Francisco.

Harris Helm J., Katz L. (2002). Project Method and preschool age, "Little Researchers" Publisher Metexmio, Athens.

Manousou,E., Tanaini, S., et al. (2010). Living Values in Education, Publisher, Orion, Athens.

Bakirtzis, K., (2002). Communication and Education, Publisher: Guteberg.

Rogers C.R., (1994). Freedom to Learn, Third Edition,Prentice Hall, Inc. New Jersey.

Tillman D, (2000).Living Values Parent Groups: A facilitator Guidel Health Communications, Inc. Deerfield Beach, Florida.

Vogt, E.E., Brown, J., Isaacs, D. (2003). The Art of Powerful Questions: Catalyzing Insight, Innovation, and Action, The World café. 